\title{
RESPONSE OF THE ENERGY BALANCE ON THE MARGIN OF THE GREENLAND ICE SHEET TO TEMPERATURE CHANGES
}

\author{
By Roger J. Braithwaite and Ole B. Olesen
}

(Grønlands Geologiske Undersøgelse, DK-1350 København K, Denmark)

\begin{abstract}
Daily ice ablation on two outlet glaciers from the Greenland ice sheet, Nordbogletscher (1979-83) and Qamanârssup sermia $(1980-86)$, is related to air temperature by a linear regression equation. Analysis of this ablation-temperature equation with the help of a simple energy-balance model shows that sensible-heat flux has the greatest temperature response and accounts for about one-half of the temperature response of ablation. Net radiation accounts for about one-quarter of the temperature response of ablation, and latent-heat flux and errors account for the remainder. The temperature response of sensible-heat flux at Qamanârssûp sermia is greater than at Nordbogletscher mainly due to higher average wind speeds. The association of high winds with high temperatures during Föhn events further increases sensible-heat flux. The energy-balance model shows that ablation from a snow surface is only about half that from an ice surface at the same air temperature.
\end{abstract}

\section{INTRODUCTION}

The Geological Survey of Greenland (GGU) has made nearly daily readings of ablation on two outlet glaciers from the Greenland ice sheet, as well as collecting simple climate data at nearby field stations (Olesen and Braithwaite, 1989). We have previously used these data to develop statistical relations between ice ablation and temperature (Braithwaite and Olesen, 1989), and we now analyse these ablationtemperature relations with a simple energy-balance model. This is useful because ablation-temperature equations will continue to be used for many practical purposes despite efforts to develop a more physically based alternative.

\section{DATA}

The data used in the present study comprise (1) observed daily ablation data from two glaciers, (2) simple daily climate data from field stations close to the glaciers, and (3) energy-balance components calculated from the simple climate data by an energy-balance model (Braithwaite and Olesen, 1990).

The ablation data come from stake 53 (at $880 \mathrm{~m}$ a.s.l.) on Nordbogletscher and stake 751 ( $790 \mathrm{~m}$ a.s.l.) on Qamanarrssûp sermia (Fig. 1). The data cover $415 \mathrm{~d}$ in JuneAugust at Nordbogletscher (1979-83) and $512 \mathrm{~d}$ at Qamanârssûp sermia (1980-86). The data mainly refer to ice ablation, as both sites have little or no winter snow although traces of new snow occur occasionally during cold periods in the summer and are taken into account in calculating the energy balance.

The daily turbulent fluxes of sensible and latent heat are calculated from air temperature, wind speed, and vapour pressure using equations given by Ambach (1986). The calculation takes account of the difference in surface roughness between ice and snow surfaces, e.g. turbulent-heat fluxes to a snow surface are $30 \%$ less than to an ice surface under the same climate conditions. The calculations assume a melting glacier surface but there are days when

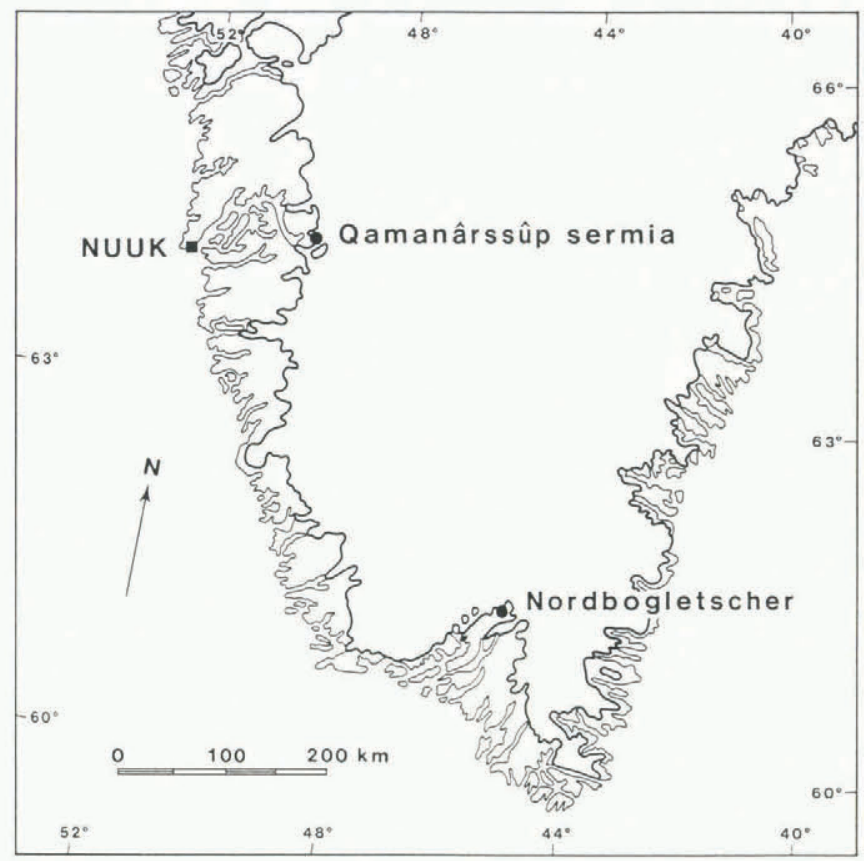

Fig. 1. Locations of two glacier-climate stations: stake 53 is on Nordbogletscher at $880 \mathrm{~m}$ a.s.l. and lat. $61^{\circ} 28^{\prime} \mathrm{N}$. and stake 751 is on Qamanârssûp sermia at $790 \mathrm{~m}$ a.s.l. and lat. $64^{\circ} 28^{\prime} \mathrm{N}$.

this is not the case, and the calculated ablation is then set to zero.

The absorbed short-wave radiation is calculated from measured incoming radiation assuming albedos of 0.3 and 0.7 , respectively, for ice and snow, i.e. a snow surface absorbs $57 \%$ less short-wave radiation than an ice surface. The long-wave radiation is calculated from air temperature and cloud amount using an equation from Ohmura (1981).

For convenience, all energy-balance components are expressed in ablation units, i.e. as $\mathrm{mm}$ water $\mathrm{d}^{-1}$ or as $\mathrm{kg} \mathrm{m}^{-2} \mathrm{~d}^{-1}$.

The errors in calculating ablation from the simple energy-balance model are summarized in Table I for different months. Although there are substantial errors on a day-to-day basis, the model is surprisingly accurate considering its simplicity.

\section{THE PROBLEM}

The observed daily ablation at any place is assumed proportional to the daily mean air temperature at the same place, and at about $1-2 \mathrm{~m}$ above the glacier surface, as long as air temperature is at or above melting: 
TABLE I. ERROR IN CALCULATING DAILY ABLATION WITH THE SIMPLE ENERGY-BALANCE MODEL (BRAITHWAITE AND OLESEN, 1990) UNITS ARE $\mathrm{mm}$ water $\mathrm{d}^{-1}$

Month

Days

Ablation

Error

Mean S.D. Mean S.D.

Nordbogletscher

\begin{tabular}{|c|c|c|c|}
\hline Jun & 111 & $27.4 \pm 21.5$ & $-2.2 \pm 13.8$ \\
\hline Jul & 149 & $35.1 \pm 19.2$ & $0.7 \pm 13.5$ \\
\hline Aug & 155 & $23.5 \pm 19.0$ & $-0.6 \pm 13.6$ \\
\hline & 415 & $28.7 \pm 20.3$ & $-0.5 \pm 13.6$ \\
\hline
\end{tabular}

Qamanârssûp sermia

\begin{tabular}{|c|c|c|c|}
\hline Jun & 145 & $35.2 \pm 27.6$ & $-5.6 \pm 19.8$ \\
\hline Jul & 182 & $53.5 \pm 27.9$ & $-0.3 \pm 19.7$ \\
\hline Aug & 185 & $34.6 \pm 27.9$ & $5.6 \pm 15.6$ \\
\hline & 512 & $41.5 \pm 29.1$ & 0.4 \\
\hline
\end{tabular}

$$
a_{t}=\alpha_{0}+\beta_{0} T_{t} \quad T_{t} \geqslant 0 \mathrm{deg}
$$

and daily ablation rate is zero for temperatures below melting:

$$
a_{t}=0 \quad T_{t}<0 \mathrm{deg}
$$

where $a_{t}$ and $T_{t}$ are respectively the daily ablation rate and temperature on day $t$, and $a_{0}$ and $\beta_{0}$ are parameters. The above relations give correlation coefficients from 0.71 to 0.83 for seven summers 1980-86 at Qamanârssûp sermia (Braithwaite and Olesen, 1989).

The $\alpha$ and $\beta$ parameters in the ablation-temperature relation vary because the surface-energy balance is implicit in them. This can be a serious drawback for studying ablation under past or future climates, or in unstudied regions, as an ablation-temperature equation for one situation need not apply to another situation. It is therefore important to understand ablation-temperature models in terms of the more fundamental energy balance.

\section{METHOD}

The method is based on Braithwaite (1981). By the least-squares algorithm, the temperature response of ablation, or slope of Equation (1), is given by:

$$
\beta_{0}=(1 / N-1)\left(1 / S_{\mathrm{T}}{ }^{2}\right) \sum_{t=1}^{t=N}\left(a_{t}-\bar{a}\right)\left(T_{t}-\bar{T}\right)
$$

where $N$ is the number of days with ablation and temperature data, $\bar{a}$ and $\bar{T}$ are the means of the respective $N$ day samples, and $S_{\mathrm{T}}$ is the standard deviation of temperature. It is understood that the samples are arranged to include only days with temperatures at or above the melting point. The intercept in the regression equation is given by:

$$
\alpha_{0}=\bar{a}-\beta_{0} \bar{T} .
$$

Ablation can be simulated by the energy-balance equation involving $M$ energy sources:

$$
a_{t}=\sum_{i=1}^{i=M} q_{i t}
$$

where $a_{t}$ is the simulated ablation, not necessarily identical https://doi.org/10.3189/50022143000009461 Published online by Cambridge University Press to observed ablation $a_{t}$, and $q_{i t}$ is the $i$ th energy source on the $t$ th day. By hypothesis, each energy source is also linked to air temperature by a regression equation:

$$
q_{i t}=\alpha_{i}+\beta_{i} T_{t}
$$

where $\alpha_{i}$ and $\beta_{i}$ are the intercept and temperature response for $i$ th energy source. Equation (6) is quite general if $\beta_{i}=0$ is not excluded a priori. Substitution of Equation (6) into Equation (5) gives:

$$
\hat{a}_{t}=\sum_{i=1}^{i=M}\left(\alpha_{i}+\beta_{i} T_{t}\right)
$$

which shows that the simulated ablation is given by the sum of regression equations linking individual energy sources to temperature. Alternatively, the $\alpha_{j}$ and $\beta_{i}$ parameters express the contribution to the overall ablationtemperature relation by the $i$ th energy source.

\section{RESULTS}

For the Nordbogletscher data set (386d with $T \geqslant 0 \mathrm{deg})$, the regression equation linking observed daily ablation $a_{t}$ to daily temperature $T_{t}$ is:

$$
a_{t}=6.4+5.93 T_{t} \quad r=0.68 .
$$

The regression equation for simulated ablation $\hat{a}_{t}$ is:

$$
\hat{a}_{t}=8.9+5.42 T_{t} \quad r=0.78
$$

where $r$ is the correlation coefficient. The corresponding equations for Qamanârssûp sermia $(480 \mathrm{~d}, T \geqslant 0 \mathrm{deg})$ are:

$$
a_{t}=-1.4+8.41 T_{t} \quad r=0.76
$$

and

$$
\hat{a}_{t}=2.6+7.58 T_{t} \quad r=0.87 .
$$

The two sets of equations are broadly similar but the Qamanârssûp sermia equations indicate higher ablation rates than for the same temperature at Nordbogletscher. Simulated ablation $\hat{a}_{t}$ is the sum of the energy sources, and differences between the $a_{t}$ and $\hat{a}_{t}$ equations reflect the effects of errors in the energy-balance calculation. These differences are small, supporting the accuracy claimed for the energy-balance model in Table $\mathrm{I}$.

The possibility that parameters in the ablation-temperature equation vary according to season, e.g. with global radiation as suggested by Gottlieb (1980) and Lundquist (1982), was examined by repeating the above calculation for each month separately. Although the results (Table II) for different months are not the same, there is no clear pattern of seasonal variation, thus agreeing with Braithwaite and Olesen (1989, fig. 3), and seasonal variations are neglected in the following discussion.

\section{Energy sources and temperature}

Regression equations were calculated for each individual energy source and temperature, and are plotted in Figures 2 and 3. The large contribution to ablation energy by short-wave radiation at $0 \mathrm{deg}$ is almost entirely offset by negative values in the other sources, so that the intercept in the ablation-temperature equation is close to zero. The numerical values of the corresponding temperature responses, i.e. slopes of the regression equations, are given in Table III. The most sensitive energy source at both sites is sensible-heat flux whose temperature response accounts for 
TABLE II. INTERCEPT $\alpha_{0}$ AND SLOPE $\beta_{0}$ IN THE RELATION BETWEEN OBSERVED ABLATION AND TEMPERATURE BY MONTH WHERE $r$ IS CORRELATION COEFFICIENT

$\begin{array}{ccccc}\text { Month } & N & \alpha_{0} & \beta_{0} & r \\ & \mathrm{~d} & \mathrm{~mm} \mathrm{~d}^{-1} & \mathrm{~mm} \mathrm{~d}^{-1} \mathrm{deg}^{-1} & \end{array}$

Nordbogletscher

$\begin{array}{lllll}\text { Jun } & 111 & 6.7 & 6.83 & 0.80 \\ \text { Jul } & 149 & 8.7 & 5.61 & 0.68 \\ \text { Aug } & 155 & 6.6 & 5.08 & 0.66 \\ & & & & \\ & 415 & 6.4 & 5.93 & 0.68\end{array}$

Qamanârssûp sermia

$\begin{array}{lrrrr}\text { Jun } & 145 & 7.3 & 6.91 & 0.77 \\ \text { Jul } & 182 & -2.3 & 8.63 & 0.70 \\ \text { Aug } & 185 & 1.6 & 7.72 & 0.80 \\ & & & & \\ & 512 & -1.4 & 8.41 & 0.76\end{array}$

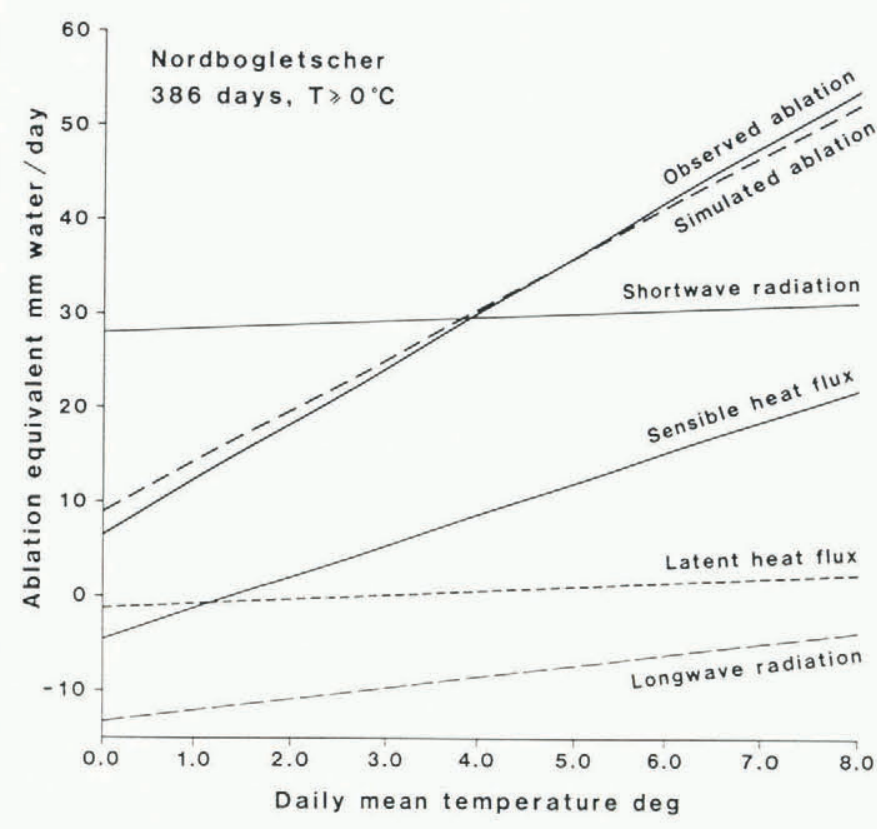

Fig. 2. Temperature variations of simulated energy balance at Nordbogletscher.

about one-half of the temperature response of ablation. Net radiation (short-wave + long-wave radiation) accounts for about one-quarter of the temperature response of ablation at both sites, while latent-heat flux and error account for the remainder.

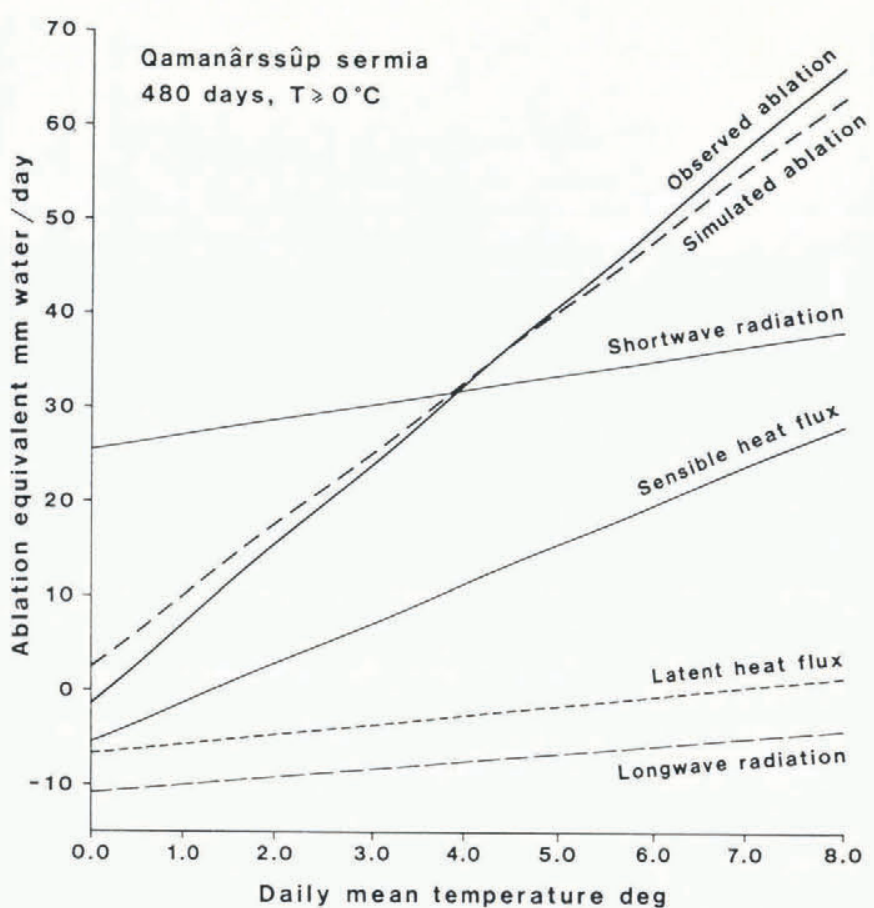

Fig. 3. Temperature variations of simulated energy balance at Qamanârssûp sermia.

\section{Effect of wind}

The temperature response of sensible-heat flux is larger at Qamanårssûp sermia than at Nordbogletscher, i.e. 4.22 compared to $3.37 \mathrm{~mm}$ water $\mathrm{d}^{-1} \mathrm{deg}^{-1}$. This partly reflects higher wind speeds at Qamanârssûp sermia, i.e. averages of 4.8 and $3.3 \mathrm{~m} \mathrm{~s}^{-1}$, respectively, and contributes to higher ablation rates there.

There is an association of high wind speeds with high temperatures under Föhn conditions which increases the sensible-heat flux at higher temperatures. This introduces an apparent non-linearity into the relation between sensibleheat flux and temperature which may explain the negative intercepts in the (assumed linear) regression equations for sensible-heat flux. The effect of this temperature-wind correlation was studied by re-running the energy-balance model with the wind speed artificially held constant (equal to the mean wind speed). This is equivalent to suppressing the temperature-wind correlation. The resulting regression lines are plotted in Figures 4 and 5 where "variable wind" models are the same as the "simulated ablation" models in Figures 2 and 3 . The temperature responses are respectively 21 and $19 \%$ less for the "constant wind" cases than for "variable wind". The effect of wind variations, and especially the temperature-wind correlation, is therefore to increase ablation at higher temperatures.

The regression lines for the "variable wind" simulation and observed ablation are not in perfect agreement, suggesting that the "variable wind" simulation still does not take full account of wind variations. This may be because

TABLE III. CONTRIBUTIONS TO THE TEMPERATURE RESPONSE OF ABLATION BY DIFFERENT ENERGY SOURCES. UNITS ARE mm water $\mathrm{d}^{-1} \mathrm{deg}^{-1}$

Source

Days

Sensible-heat flux

Latent-heat flux

Short-wave radiation

Long-wave radiation

Error
Nordbogletscher

415

\section{Qamanârssûp sermia}




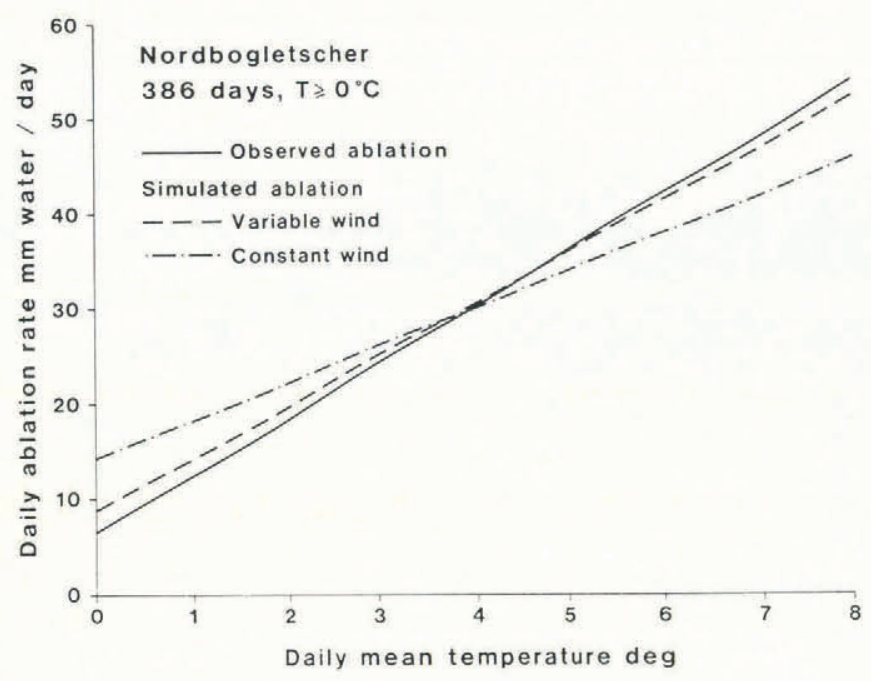

Fig. 4. Ablation-temperature regression lines for different wind conditions at Nordbogletscher.

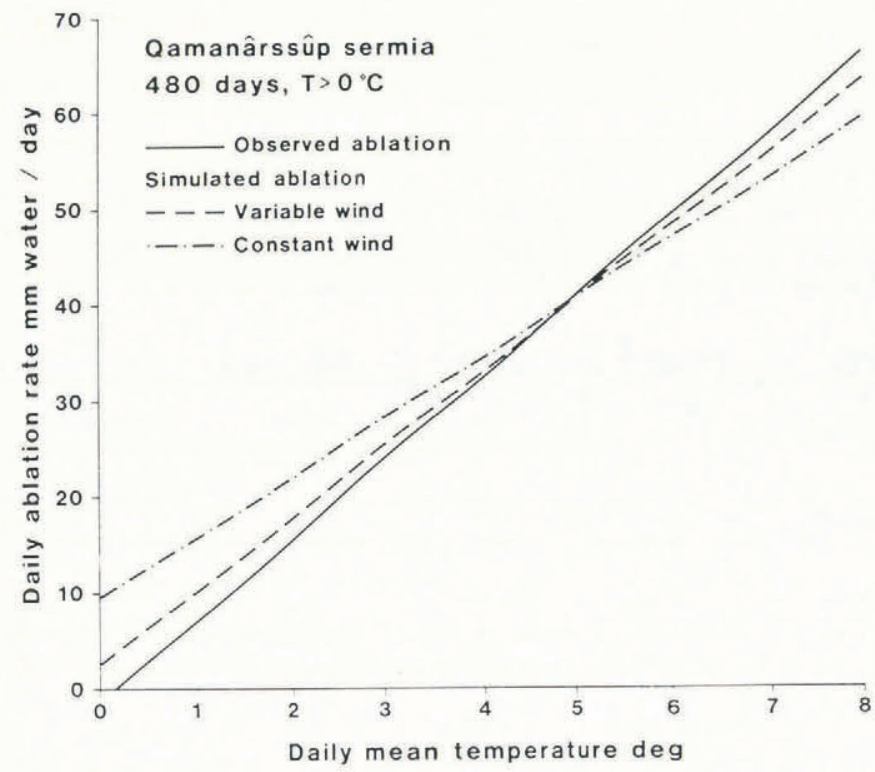

Fig. 5. Ablation-temperature regression lines for different wind conditions at Qamanârssûp sermia.

the model uses daily means of temperature and wind speed for the simulations and their product might not fully reflect the actual temperature-wind associations in Föhn events. This could be avoided in future by calculating sensible-heat flux with sub-daily data for wind and temperature.

The present results demonstrate the quantitative importance of the temperature-wind correlation for ablation but research on boundary-layer processes is required to understand the mechanisms of Föhn events.

\section{Effect of snow cover}

The observed ablation data mainly refer to ice ablation, so it is difficult to assess directly the effects of snow cover. However, the effect was simulated by re-running the energy-balance model with artificial assumptions about the glacier surface, i.e. ablation was calculated for notional ice and snow surfaces. The resulting ablation-temperature lines are plotted in Figures 6 and 7 where the "trace of snow" lines are the same as the "simulated ablation" lines in Figures 2 and 3.

Snow is fairly rare at the two sites, i.e. with average frequencies of only 4 and $3 \mathrm{~d} /$ month, respectively, so that "ice" and "trace of snow" simulations are similar. The fact that the "trace of snow" lines do not coincide with the "observed ablation" lines suggests that the simulations still do not take full account of the effects of snow. By https://doi.org/10.3189/50022143000009461 Published online by Cambridge University Press

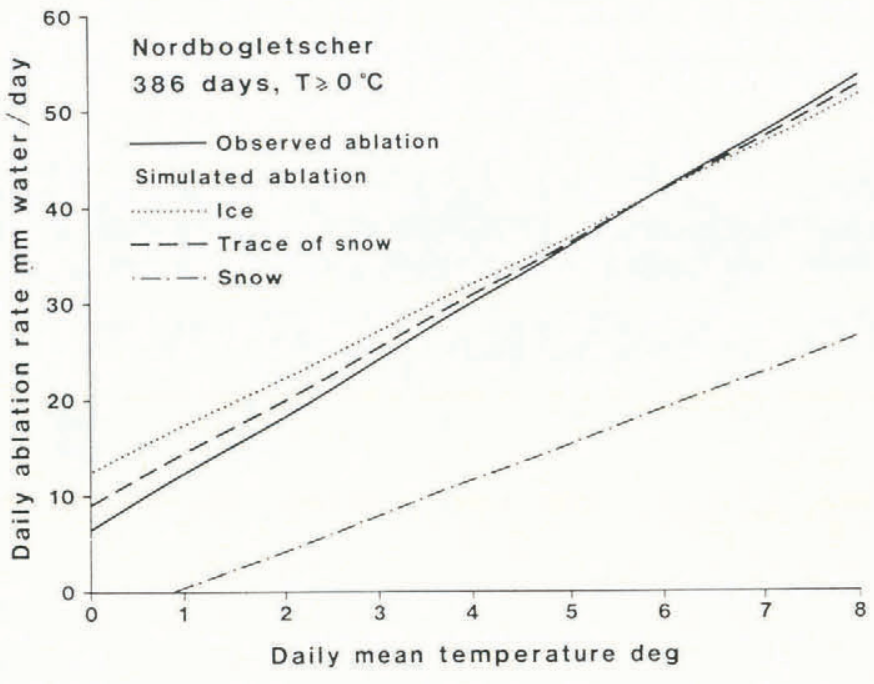

Fig. 6. Ablation-temperature regression lines for different surface conditions at Nordbogletscher.

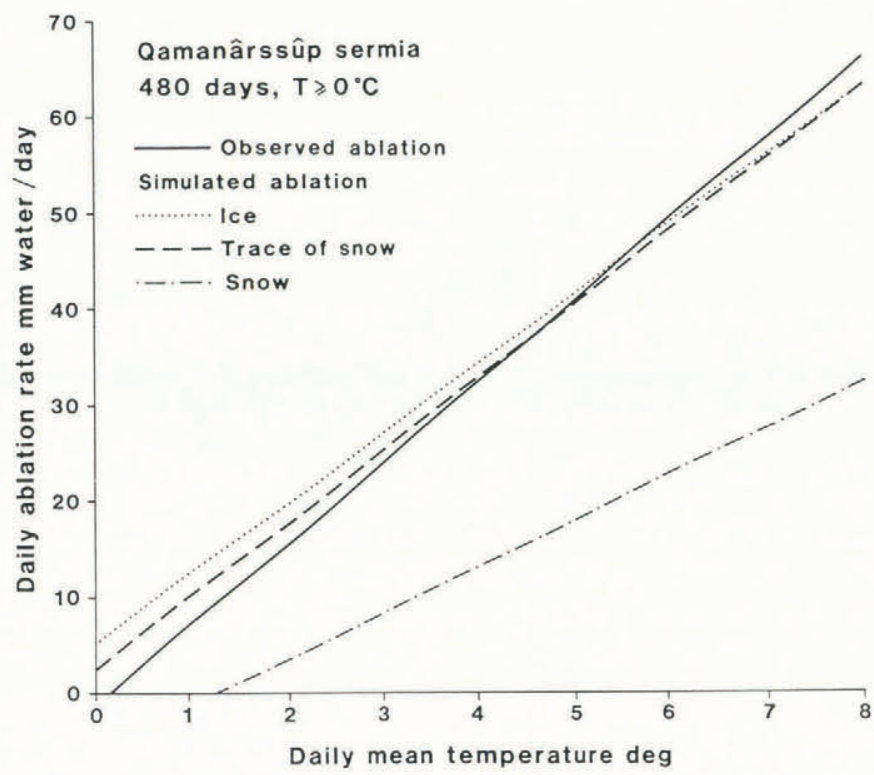

Fig. 7. Ablation-temperature regression lines for different surface conditions at Qamanârssûp sermia.

comparison, assumption of a complete snow cover reduces ablation dramatically. For example, at an air temperature of $5 \mathrm{deg}$, snow ablation is nearly $60 \%$ less than ice ablation, while the difference drops to less than $50 \%$ at $10 \mathrm{deg}$. This partly reflects the high albedo and low surface roughness assumed for snow surfaces but also the greater difficulty in maintaining snow surfaces at the melting temperature compared to ice surfaces. The model still assumes an identity between melting and ablation that may not be true for a thick snow cover, e.g. refreezing of melt water as ice lenses or superimposed ice could further reduce snow ablation compared with ice ablation.

\section{CONCLUSIONS}

Ice ablation at Nordbogletscher and Qamanârssûp sermia is related to air temperature by a two-parameter equation which explains about one-half of daily ablation variance.

The ablation-temperature relation can be explained in terms of energy balance whereby the biggest contribution to the temperature response of ablation is provided by sensible-heat flux with smaller contributions from radiation and latent-heat flux.

Under Föhn conditions, high wind speeds are associated with high temperatures which increases the sensible-heat flux at high temperatures. 
A complete snow cover reduces ablation dramatically compared with an ice surface at the same temperature, partly reflecting high albedo and low surface roughness of snow surfaces.

\section{ACKNOWLEDGEMENTS}

This paper is published by permission of the Geological Survey of Greenland. The field station at Nordbogletscher 1978-83 was partly funded by the European Economic Community (EEC) and by the Danish Energy Ministry, while the Qamanârssûp sermia station was wholly funded by the Geological Survey of Greenland. The work at Nordbogletscher was led by P. Clement in the period 1980-83.

\section{REFERENCES}

Ambach, W. 1986. Nomographs for the determination of meltwater from snow- and ice surfaces. Ber. Naturwiss. Med. Ver. Innsbruck, 73, 7-15.

Braithwaite, R.J. 1981. On glacier energy balance, ablation, and air temperature. J. Glaciol., 27(97), 381-391.
Braithwaite, R.J. and O.B. Olesen. 1989. Calculation of glacier ablation from air temperature, West Greenland. In Oerlemans, J., ed. Glacier fluctuations and climatic change. Dordrecht, etc., Kluwer Academic Publishers, 219-233.

Braithwaite, R.J. and O.B. Olesen. 1990. A simple energybalance model to calculate ice ablation at the margin of the Greenland ice sheet. J. Glaciol., 36(123), 222-228.

Gottlieb, L. 1980. Development and applications of a runoff model for snowcovered and glacierized basins. Nord. Hydrol., 11(5), 255-272.

Lundquist, D. 1982. Modelling runoff from a glacierized basin. International Association of Hydrological Sciences Publication 138 (Symposium at Exeter 1982 Hydrological Aspects of Alpine and High-Mountain Areas), 131-136.

Ohmura, A. 1981. Climate and energy balance on Arctic tundra, Axel Heiberg Island, Canadian Arctic Archipelago, spring and summer 1969, 1970 and 1972. Zürcher Geogr. Schr., 3.

Olesen, O.B. and R.J. Braithwaite. 1989. Field stations for glacier-climate research, West Greenland. In Oerlemans, J., ed. Glacier fluctuations and climatic change. Dordrecht, etc., Kluwer Academic Publishers, 207-218. 